\title{
A Knowledge Level Analysis of Designated Male Receptor: A Basis of Making Public Service Ads for Family Planning Program
}

\author{
Christina Whidya Utami ${ }^{1}$, Monika Teguh ${ }^{2}$, Hilda Yunita Wono ${ }^{2}$, and Charly \\ Hongdiyanto ${ }^{1}$
}

${ }^{1}$ International Business Management Department, School of Management and Business, Universitas Ciputra, Surabaya, Indonesia

${ }^{2}$ Communication Science Department, School of Communication Science and Media Business, Universitas Ciputra, Surabaya, Indonesia

Corresponding Author:

Monika Teguh

monika.teguh@ciputra.ac.id

Received: 30 December 2019

Accepted: 29 January 2020

Published: 6 February 2020

Publishing services provided by Knowledge E

(c) Christina Whidya Utami

et al. This article is distributed

under the terms of the Creative

Commons Attribution License,

which permits unrestricted use

and redistribution provided that

the original author and source are credited.

Selection and Peer-review unde the responsibility of the 6 th ICOEN 2019 Conference Committee.

\begin{abstract}
In order to support the establishment of a prosperous Indonesian society, the Government of Indonesia in its Long Term Development Plan begins to implement human quality improvement programs. One of them is Family Planning program. Currently, family planning program has been widely used, especially in cities with high population density such as Surabaya. But what is commonly known to the public is the program for female, while the program for male has little interest. To balance the male and female program receptors, the Surabaya city government will launch a series of public service ads. To support the effectiveness of these advertisements, the knowledge level of the male receptor candidate is studied. The results show that the knowledge level of male receptors is still moderate. Generally they do not understand about the vasectomy procedure such as the procedure without a knife, its benefit such as effectiveness in removing sperm, and its side effects such as the healing time. Therefore these things should be considered when designing ads.
\end{abstract}

Keywords: knowledge level, family planning program for male, public service ads

\section{Introduction}

Every country certainly wants its people to have a prosperous life. Therefore, efforts are made to support the establishment of a prosperous, healthy and peaceful society. The Indonesian government itself in an effort to build the nation's welfare makes the Long-Term Development Plan for 2005 -2025. One of the main focuses in the plan is the development of human resources that includes the quality, quantity and mobility of the population. Quality of the population looks at aspects of health and nutrition levels, productivity, education, noble character, and social welfare. The quantity of the population sees from the aspect of the number and rate of growth, whereas population 
mobility looks at the aspect of displacement and population distribution. This plan also shows that there is a significant relationship between quantity and quality of population. The decline in the rate of population growth caused by declining birth rates has implications for the increase in the quality of the population that can be seen in the increasing health and nutrition conditions, and public education. The data show an increase in life expectancy from 1960 which was only 41.0 years to 66.2 years in 2000. In addition, the rate of population participation in education also increased. In 2002 , the gross enrollment rate at all levels of primary education increased where the rate was equal to $105.99 \%$, junior high school equivalent reached $79.81 \%$, and high school rate equal to $98 \%$. Literacy figures also increased to $89.51 \%$ [1]. Therefore, efforts to regulate the birth rate are also one of the policies that need to be carried out by the government. In Indonesia, the effort to regulate birth rate is realized through Family Planning program. The purpose of the family planning is to improve the health and welfare of the community, especially for mothers and children. Until now, this family planning program is implemented in each region by taking into account areas with high population density [2].

\subsection{Statement of a problem}

Surabaya is the second largest city in Indonesia with a high population density. According to Department of Population and Civil Registration of Surabaya, the population of Surabaya until the end of 2017 reached 3.065 .000 people [3]. This amount has exceeded the projection made by the Central Bureau of Statistic, which predicted Surabaya population to be around 2.896 .600 people by the end of 2017 [4]. Seeing this condition, Surabaya city government has promoted family planning program. The new problem that arises from the current family planning program in Surabaya is the low number of male receptors. The male receptors of family planning program by 2015 , with the vasectomy method in particular, are only $0,26 \%$ of all program receptors [5]. The newest data from the head of Family Planning Division of The Office of Population Control, Women's Empowerment and Child Protection state that only 212 persons by 2016 and 229 persons by 2017 are using the method. This is starting to become the government's attention because many couples do not join family planning program because the wife suffers from health problems such as high blood pressure, diabetes, heart disease, lung disease, vaginal bleeding, systemic or pelvic infections, and allergies. In that condition, the husbands mostly also do not aware of male family planning program and they choose to not control the birth rate [6]. In order to raise 
the awareness for the male receptors for family planning program in Surabaya, the government will make public service ads. To make sure that the ads will be well accepted by the program objectives, the analysis of knowledge level is conducted.

Knowledge is the result of human effort to understand an object through his senses. Mostly human knowledge is obtained through the eyes and ears. A study in Buleleng, Bali shows that knowledge has a significant influence on vasectomy participation. This study took sample of 87 people with simple random sampling technique of 112 designated male receptors. The research instrument is a questionnaire with hypothesis test using logistic regression analysis. The results of this study indicate a significant positive relationship between knowledge with the participation of family planning program for male. In this study it was explained that designated receptors with a high level of knowledge were likely to participate in the program 9,062 times greater than target targets with low knowledge level [7]. Another study in district of Rancaekek, Bandung shows that there is a relationship between knowledge and program participation. District of Rancaekek is one area with low vasectomy receptors. In fact the community has a desire to support the vasectomy program, but unfortunately the knowledge they have is still low. It is hoped that there will be a government effort to provide further counseling through various media so that public knowledge can improve [8]. Another study ever conducted in Surabaya shows that cognition or knowledge is part of consumption behavior. This pattern of consumption behavior can be a reference for designing mediated message including advertising [9].

\section{Methods}

The method used in this research was descriptive quantitative. The researcher took the data from the subject once without intervening. There was no pre-test nor posttest. The data collection was done once based on the natural conditions as they were. This research was conducted in the city of Surabaya, East Java, Indonesia in May-June 2018. The population of the study was the target group of the male vasectomy or family planning program. The criteria for research subjects were men, aged 15-49 years old, married, wife's age of at least 24 years, at least having one child, and healthy conditions for a vasectomy program.

Because of these specific criteria, the numbers of the population were unknown. The minimum samples were to use the proportion of standard normal deviation at a 
confidence level ( $z$ ) of 1.64, percentage picking a choice or response (p) at 0.5 and confidence interval (c) at 0.05 [10]. The sampling formula is as follows:

$$
n=\frac{z^{2}(p)(p-1)}{c^{2}}
$$

From this formula, the minimum numbers of the samples were 269 people. For practical purposes, the numbers of the samples included 350 people. The sampling technique in this study was purposive sampling [11], the respondents were people who met the criteria of the target vasectomy program. The instruments for the data collection were in the form of the questionnaires. This questionnaire used a Guttman scale with a dichotomous model: true or false [12]. The data came from the primary data sources or the respondents. For the data analysis, this study used univariate analysis. Univariate analysis aimed to describe or explain the characteristics of the research variables. The research variable was the level of respondents' knowledge of vasectomy contraceptives, and percentage is used as a basis for analysis.

\section{Results}

The data from the study are as follows:

TABLE 1: Frequency Distribution Based on Respondent Characteristics $(n=350)$.

\begin{tabular}{l|l|}
\hline \multicolumn{2}{c}{ Respondent } \\
\hline Age & $\begin{array}{l}\text { 23-36 years } \\
\text { 37-49 years }\end{array}$ \\
\hline Type of work & Blue Collar \\
\hline Wge of Marriage & 19 years old \\
\hline Number of children & $1-2$ people \\
\hline & 3 people or more \\
\hline
\end{tabular}

\begin{tabular}{|c|}
\hline Frequency \\
\hline 163 \\
\hline 187 \\
\hline 70 \\
\hline 280 \\
\hline 156 \\
\hline 194 \\
\hline 270 \\
\hline 80 \\
\hline
\end{tabular}

\begin{tabular}{|c|}
\hline Percentage (\%) \\
\hline $47 \%$ \\
\hline $53 \%$ \\
\hline $20 \%$ \\
\hline $80 \%$ \\
\hline $45 \%$ \\
\hline $55 \%$ \\
\hline $77 \%$ \\
\hline $23 \%$
\end{tabular}

Table 1 shows that 53\% of respondents are between $37-49$ years. $47 \%$ are $23-36$ years. Most of them (80\%) work as white collars or jobs that require special skills, knowledge or expertise. The remaining $20 \%$ work as a blue collar or work that requires lower expertise. The number of respondents whose marriage age ranges from 10-41 years or more are $55 \%$. There are $45 \%$ of those with $1-9$ years of marriage. $23 \%$ of the respondents have 3 children. Meanwhile, the respondents with 1-2 children are as much as $77 \%$. The distribution of respondents is quite good. This is because information about 
the vasectomy program should be distributed to people who still have few children, so that they can plan the birth rate.

TABLE 2: Frequency Distribution of Knowledge Levels on Vasectomy Programs $(n=350)$.

\begin{tabular}{l|c|c|}
\hline Knowledge Level Category & Frequency & Percentage (\%) \\
\hline Low & 70 & $20 \%$ \\
\hline Medium & 267 & $76 \%$ \\
\hline High & 13 & $4 \%$ \\
\hline
\end{tabular}

Table 2 shows the level of knowledge of respondents. The research questionnaire has 19 questions related to information about the vasectomy program. Questions in the questionnaire included vasectomy user requirements, vasectomy procedures, vasectomy safety levels, vasectomy side effects, vasectomy benefits, and vasectomy costs. If the respondent answers correctly 0-9 of the questions, they are classified as a group with a low level of knowledge. If the respondent succeeds in answering correctly 10-15 questions, they are classified as groups with moderate knowledge. If they can answer 16-19 questions, they are classified as a group with a high level of knowledge of the vasectomy program.

Based on the results of the analysis, the majority of respondents are at the level of moderate knowledge, as much as $76 \%$. Respondents with low knowledge are $20 \%$. There are very few respondents with high knowledge or about $4 \%$. This finding shows that the program targets still need to have more accurate information so people can have better understanding about the vasectomy program. This finding suggests the importance of making relevant information media for vasectomy programs such as public service advertisements.

To make public service advertisements, it is necessary to pay attention to essential information. This is to avoid respondents' misunderstandings. The followings are the results of the responses from the respondents.

Based on Table 3, three topics have received $80 \%$ or more correct answers. The topic sufficiently understood by the respondents is related to the age limit of marriage for vasectomy users, the limitation of the number of children for vasectomy users, and the effect of vasectomy on the decrease in the body's resistance. Most respondents have already known that people recommended to join a vasectomy are not limited by the age of marriage. However, they have to pay attention to the number of children. It is recommended that they have two children before doing a vasectomy procedure. In addition, they also understand that the vasectomy do not cause a decrease in endurance 
TABLE 3: Frequency Distribution of Correct Answers in the Questionnaire about Vasectomy Programs ( $n$ $=350$ ).

\begin{tabular}{|c|c|c|c|}
\hline No & Topics & Frequency & Percentage (\%) \\
\hline 1 & Limitation of vasectomy users & 212 & $61 \%$ \\
\hline 2 & Limitation of marriage age for vasectomy users & 299 & $85 \%$ \\
\hline 3 & Limit the number of children for vasectomy users & 304 & $87 \%$ \\
\hline 4 & Vasectomy surgery procedure & 244 & $70 \%$ \\
\hline 5 & $\begin{array}{l}\text { Comparison of vasectomy wounds with } \\
\text { circumcision }\end{array}$ & 200 & $57 \%$ \\
\hline 6 & $\begin{array}{l}\text { Comparison of vasectomy healing with } \\
\text { circumcision }\end{array}$ & 192 & $55 \%$ \\
\hline 7 & Vasectomy procedure without a knife & 105 & $30 \%$ \\
\hline 8 & Vasectomy healing time & 167 & $48 \%$ \\
\hline 9 & Vasectomy versus castration & 254 & $73 \%$ \\
\hline 10 & The effects of vasectomy on impotence & 271 & $77 \%$ \\
\hline 11 & Vasectomy effects on decreased stamina & 255 & $73 \%$ \\
\hline 12 & Vasectomy effects on decreased immune system & 281 & $80 \%$ \\
\hline 13 & Vasectomy effect on decreased sexual desire & 236 & $67 \%$ \\
\hline 14 & The effect of vasectomy on ejaculation & 167 & $48 \%$ \\
\hline 15 & Vasectomy effectiveness in removing sperm & 102 & $29 \%$ \\
\hline 16 & Sexual procedure after vasectomy & 107 & $31 \%$ \\
\hline 17 & Cost for doing a vasectomy & 160 & $46 \%$ \\
\hline 18 & Effectiveness of vasectomy to prevent pregnancy & 272 & $78 \%$ \\
\hline 19 & $\begin{array}{l}\text { Vasectomy abilities to prevent transmission of } \\
\text { sexually transmitted diseases }\end{array}$ & 210 & $60 \%$ \\
\hline
\end{tabular}

making them susceptible to disease. Therefore, these three topics can be minimized in advertisements because they are sufficiently understood.

\section{Discussion}

There are $60-70 \%$ of respondents giving correct answers to 8 topics. This finding indicates that these topics are quite familiar to them. However, quite a lot still do not understand the vasectomy topic. This topic must still be discussed even though they are not the main points. The first topic is about the limitations for vasectomy users. Many respondents do not know that there are conditions to meet in order to take vasectomy program, one of which is a health condition. The second topic is the procedure of vasectomy. This is actually a small operation, not a big, high-risk operation. 
The next topic is that the vasectomy is not the same as castrated, and it does not cause impotence. Vasectomy only closes the sperm duct, and it does not cut off the testicles or muscles in the penis area. This topic still needs to be considered because this is a sensitive and necessary topic to clarify. People have to understand medical procedures, and telling people about it can prevent myths.

The next topic is regarding the effect of vasectomy on decreased stamina and sexual arousal. Vasectomy is not a major surgery that leaves wounds or takes organs. Therefore, vasectomy does not decrease stamina or sexual desire. This topic must be emphasized to prevent myths or misconceptions about vasectomy program. Another topic is the effectiveness of vasectomy in preventing pregnancy and transmission of sexually transmitted diseases. Vasectomy is very effective in preventing pregnancy. This is because the vasectomy. It is able to prevent sperm channeled. However, this method cannot prevent sexually transmitted diseases. This is because the vasectomy procedure is done only on the sperm duct. Meanwhile, transmission of sexually transmitted diseases can occur through sexual organs exposed during intercourse. Vasectomy does not protect users from sexually transmitted diseases, and a vasectomy cannot be used as an excuse to have free sex because they will feel immune to the disease after a vasectomy. This finding shows that many respondents are still misunderstood or have not received information related to vasectomy at all. Topics about vasectomy need to be processed and made the main information in public service advertisements. The first topic is the effectiveness of vasectomy in removing sperm. Only $29 \%$ were able to answer correctly. These findings suggest the importance of information about a vasectomy procedure: closing the sperm duct to prevent sperm from entering the semen duct. The next topic with a low true response (30\%) is a vasectomy procedure without a knife and a sexual procedure after a vasectomy. Most respondents do not know the latest medical procedures: vasectomy without using a knife. This procedure only causes light wound and it is easy to heal. This vasectomy procedure makes the respondent comfortable. After doing a vasectomy, the sperm still remains normal. Therefore, it is highly recommended that people use condoms during the sexual intercourse within a certain period of time according to the advice of medical personnel. The next topic is the cost of doing a vasectomy. Vasectomy requires small surgical procedure. The respondents generally thought that the cost for the operation needs a lot of money. Conversely, vasectomy is a government-supported program. Therefore, people interested in this program will get free services. This must be conveyed in the ad along with the contact. In so doing, people can find it easy to get the information if they want to get free services. The next topic is about ejaculation. 
Many think that vasectomy causes ejaculation difficulties. In fact, ejaculation is not related to sperm ducts. This needs to be clarified to avoid misunderstandings. The subsequent topics are related to healing from vasectomy. Many do not know that a very small vasectomy wound is only about $0.5-1 \mathrm{~cm}$. The wound caused by vasectomy is much lighter than circumcision. Healing from vasectomy surgery is much faster than circumcision. This is different from what most people commonly view that vasectomy is as something painful, and it would take a long time for recovery. In short, when you have survived the circumcision process, you will also be able to pass through the vasectomy.

\section{Conclusion}

The level of knowledge of the target people about a vasectomy program in Surabaya is mostly in the medium category. There are $76 \%$ in the medium category, $20 \%$ in the low category, and only $4 \%$ in the high category. This finding shows that people still need information about vasectomy programs. This finding implies that people's knowledge about vasectomy is still poor. As a result, public service advertisements have to be prepared carefully.

There are two types of information: information that is sufficiently understood and the information that is poorly understood. The information that people sufficiently understand needs to be included in the advertisement; however, it does not have to be the main information. The information that is poorly understood must be included as the main information in the ad. Some other information that is quite understood includes the information about the limits of vasectomy users, vasectomy differences with castration, vasectomy and impotence, vasectomy effects on decreased stamina and sexual desire, and vasectomy effectiveness in preventing pregnancy and transmission of sexually transmitted diseases. Some poorly understood information includes the effectiveness of vasectomy in removing sperm, a knife-free vasectomy procedure, a sexual procedure after a vasectomy, the cost of doing a vasectomy, the effect of a vasectomy on ejaculation, and the healing process of a vasectomy.

\section{Funding}

This work was funded by the Directorate of Research and Community Service, Directorate General of Research and Development Strengthening, Ministry of Research, Technology and Higher Education. 


\section{Acknowledgement}

This paper is the output of Higher Education Applied Research (PT-UPT) in 2018 funded by the Directorate of Research and Community Service, Directorate General of Research and Development Strengthening, Ministry of Research, Technology and Higher Education.

\section{Conflict of Interest}

The authors have no conflict of interest to declare.

\section{References}

[1] Badan Perencanaan Pembangunan Nasional. (2004). Visi dan Arah Pembangunan Jangka Panjang (PJP) Tahun 2005 - 2025. Retrieved Maret 23, 2017, from Bappenas.go.id: http://www.bappenas.go.id/files/1814/2057/0437/RPJP_2005-2025.pdf

[2] Badan Perencanaan dan Pembangunan Nasional. (2010). Keluarga Berencana. Retrieved Maret 23, 2017, from Bappenas.go.id: www.bappenas.go.id/index.php/ download_file/view/9409/1770/

[3] Aini, N. (2018, Januari 1). Awal Tahun 2018, Disependukcapil Prediksi Jumlah Warga Pendatang di Surabaya Tak Ada Lonjakan. Retrieved from TribunJatim.com: http://jatim.tribunnews.com/2018/01/01/awal-tahun-2018-disependukcapilprediksi-jumlah-warga-pendatang-di-surabaya-tak-ada-lonjakan

[4] Badan Pusat Statistik Kota Surabaya. (2017). Kota Surabaya Dalam Angka 2017. Surabaya: Badan Pusat Statistik Kota Surabaya.

[5] Bapemas KB Surabaya. (2016). Jumlah Peserta KB Aktif Tahun 2012-2015. Surabaya: Bagian Kesejahteraan Rakyat Pemerintah Kota Surabaya.

[6] Yudianto, G. P. (2018, March 1). Perkembangan Program Keluarga Berencana Untuk Pria di Surabaya. (H. Y. Wono, Interviewer)

[7] Wahyuni, N. P., Suryani, N., \& Murdani, P. K. (2013). Hubungan Pengetahuan Dan Sikap Akseptor KB Pria Tentang Vasektomi Serta Dukungan Keluarga Dengan Partisipasi Pria Dalam Vasektomi (Di Kecamatan Tejakula Kabupaten Buleleng). Jurnal Magister Kedokteran Keluarga Vol 1, No 1, 80-91.

[8] Nurrita, M., Komariah, M., \& Ermiati. (2012). Pengetahuan dan Sikap Suami Terhadap Kontrasepsi Mantap Vasektomi Di Kecamatan Rancaekek. Student e-Journal Vol 1, No 1, 29. 
[9] Wono, H. Y., \& Teguh, M. (2016). Perilaku Konsumsi Media Pada Pria Di Surabaya (Studi Pada Upaya Peningkatan Partisipasi KB Pria). Jurnal SCRIPTURA, Vol. 6, No. 2, 76-81.

[10] Shore, J. H. (2009). Basic Statistics for Trainers. Infoline Vol. 26, Issue 0906, 1-16. Semiz, B. B. (2016). Comparison of Stratified Sampling and Quota Sampling in Terms of Population Mean. Proceedings of The 7th MAC 2016 (pp. 97-103). Prague: MAC Prague Consulting Ltd

[11] Babbie, E. (2016). The Practice of Social Research. Canada: Cengage Learning. 